Cahiers du MONDE RUSSE

\section{Cahiers du monde russe}

Russie - Empire russe - Union soviétique et États indépendants

\title{
The papers on foreign and international policy in the Russian archives
}

The Stalin years

\section{Silvio Pons}

\section{(2) OpenEdition \\ Journals}

Electronic version

URL: http://journals.openedition.org/monderusse/12

DOI: $10.4000 /$ monderusse. 12

ISSN: $1777-5388$

Publisher

Éditions de l'EHESS

Printed version

Date of publication: 1 January 1999

Number of pages: $235-250$

ISBN: 2-7132-1314-2

ISSN: $1252-6576$

\section{Electronic reference}

Silvio Pons, «The papers on foreign and international policy in the Russian archives », Cahiers du

monde russe [Online], 40/1-2 | 1999, Online since 15 January 2007, Connection on 03 May 2019. URL http://journals.openedition.org/monderusse/12 ; DOI : 10.4000/monderusse.12 


\title{
THE PAPERS ON FOREIGN AND INTERNATIONAL POLICY IN THE RUSSIAN ARCHIVES
}

\author{
The Stalin years
}

THIS ARTICLE IS BASED on research undertaken on three different topics in the history of Soviet foreign policy under Stalin: a) Soviet responses to the European crises during the second half of the 1930s and the role of the USSR in the origins of WW $2{ }^{1}$ b) Soviet foreign policy and the establishment of the Cominform (1947$1948) ;{ }^{2}$ c) Soviet policy towards Italy in the post-war years (1943-1948). ${ }^{3}$ My paper does not aim to present a general picture of research problems, opportunities and perspectives in the field of Soviet foreign policy. Most probably, the 1920s specialist, in particular, could find significant discrepancies with what the paper reports. However, I maintain that some conclusions can be drawn even on this basis. For the points enlisted above are related to research in different archives which, to some extent, should be considered as typical for the historian of Soviet

1. See S. Pons, Stalin e la guerra inevitabile (Torino: Einaudi, 1995), forthcoming in English as Stalin and the inevitable war 1936-1941; and also S. Pons, "The Comintern and the issue of war in the 1930s: the debate in March-April 1936," in M. Narinsky and J. Rojahn, eds, Centre and periphery. The history of the Comintern in the light of new documents (Amsterdam: International Institute of Social History, 1996): 114-121.

2. See S. Pons, "The twilight of the Cominform," in G. Procacci, ed., G. Adibekov, A. Di Biagio, L. Gibianskii, F. Gori, S. Pons, co-eds, The Cominform. Minutes of the three conferences 1947/1948/1949 (Milano: Feltrinelli, 1994): 483-503; and S. Pons, "La direction stalinienne et le Kominform: quelques rélexions sur la Conférence de 1947," in SergeWolikow, dir., Une histoire en révolution? Du bon usage des archives, de Moscou et d'ailleurs (Dijon: Université de Bourgogne, 1996): 177-185.

3. See S. Pons, "A challenge let drop: Soviet foreign policy, the Cominform, and the PCI, 19471948," in F. Gori, S. Pons, eds, The Soviet Union and Europe in the Cold War 1943-1953 (London: Macmillan, 1996): 246-263; and S. Pons, "La place de l'Italie dans la politique extérieure de l’URSS 1943-1944,” Communisme, 49-50 (1997): 91-106. 
foreign policy. The research was undertaken in the following archives: the Archive of Foreign Policy of the Russian Federation (Arkhiv Vneshnei Politiki Rossiiskoi Federatsii - AVP RF) - that is to say, the Archive of the Ministry of Foreign Affairs of the Soviet Union; the archives of the Communist International (Rossiiskii Tsentr Khraneniia i Izucheniia Dokumentov Noveishei Istorii RTsKhIDNI, mainly f. 495); the papers of the Foreign Policy Department of the Central Committee of the CPSU (RTsKhIDNI, f. 17, op. 128 and 137); the Cominform fond (RTsKhIDNI, f. 575). Moreover, some personal fondy are of particular relevance to the study of foreign policy: among the available fondy one should stress the importance of Zhdanov's personal papers (RTsKhIDNI, f. 77) for the post-war years.

It is important to bear in mind that the Russian archives are only selectively accessible, particularly those regarding foreign and international policy. This is due to different circumstances. However, the main problem is the situation of the AVP $\mathrm{RF}$ - the main place for any researcher in this field, but also one of the most impervious places for carrying out "normal" research. A major problem is the lack of opisi (or the doubtful usefulness thereof). ${ }^{4}$ Under this respect, not much has changed since this archive was formally opened to foreign visitors, in the years 1989-1990. On the other hand, substantial changes have taken place in the availability of materials, since a process of declassification, albeit very slow, has been carried out over the past years. However, only a few opisi are available, which does not help our understanding of the archival collections and of the declassification process. Moreover, the degree of correspondence between opisi entries and dela contents is not satisfactory. For example, in the opisi on Italy (f. 098) for the years 1943-1948, the content of dela is very poorly recorded (and it is not recorded at all for those dela not yet declassified). Only the internal opisi of each single delo are really accurate. Thus, the general situation of the archive is a peculiar one. It is possible to undertake research but it is almost impossible to understand what part of the collections one has examined and what part still remains to be seen. In other words, the scholar is not really in control of his research.

This is not to say that the impact of research in the Arkhiv Vneshnei Politiki should be underestimated. At least up to 1999, scholars have been allowed to collect relevant new documents, throwing new light on important problems. After all, the first purpose of most historians approaching the AVP RF is to get a better knowledge of diplomatic correspondence, than that provided by official

4. Only a general putevoditel' is available, which does not substitute the role of opisi. The researcher working in the AVP RF knows very well one has to conform to a set of rules. A detailed "research plan" has to be submitted for approval some months before starting the research, listing all the documents required. Materials will then be submitted according to the decisions of the archivists and to their understanding of the researcher's requests. One is expected to follow the plan closely, and documents booked after reading the opisi (if they are available on that specific period and topic) will not be given out if not considered to be in the plan. Moreover, the researcher has no contact with the people working in the archive (except for those working in the reading room, who are not responsible for the choice of the materials). 
publications of diplomatic documents. This is what can be done for the 1930s, though only in relation to some of the main correspondences and not without problems. Let us take for example the Litvinov-Maiskii perepiska during the Spanish crisis in the years 1936-1937 and during the Czechoslovak crisis in 1938.5 This is obviously central to pre-war history of Soviet foreign policy, given the position of Maiskii in London and his close personal relationship to Litvinov. On several issues, the archival files provide us with evidence which could not be obtained through the published collections. Among the most significant discoveries is Litvinov's view on the Soviet decision for intervention in Spain in OctoberNovember 1936 which is no longer open to speculation. From a letter of Maiskii we understand that Litvinov was against intervention and claimed that it should be stopped as soon as possible. ${ }^{6}$ This gives a relevant insight on political opinions and conflict about foreign affairs within the Soviet élite, confronted with the major crises that led to World War II. Moreover, Maiskii did not share Litvinov's view, nevertheless defending the decision to intervene as a means to enforce "collective security" - that is to say, in quite a different way from the isolationist and/or ideological arguments supposedly put forward by those closely associated with Stalin's entourage. Hence, a relative articulation of the political discourse emerges, which appears more complex than expected before the opening of the archives.

Nevertheless, such an example could also be used in order to demonstrate the inadequacy of the archives, in their present state, for a proper understanding of policy-making. Firstly, in the same correspondence with Maiskii, one can easily spot gaps in Litvinov's letters. Reference can be found to letters which have not been preserved in the files, and no letters have been collected for significant periods. ${ }^{7}$ Presumably, Litvinov's instructions to Maiskii also went through different channels, but we have no access to such documentation. Secondly, not all the correspondences are available. In our case, the Litvinov-Rozenberg correspondence is not, and this is an obvious limitation: even Maiskii's letter quoted above referred to Litvinov's position as formulated in a letter to Rozenberg in Spain. One can hardly hope to have a deeper understanding of Litvinov's position without direct access to these documents.

Thirdly, Litvinov's letters to Stalin and to other leaders of the CPSU in the 1930s are also not always available. ${ }^{8}$ This documentation should, in principle, provide us with decisive insights on decision-making regarding foreign policy, and

5. AVP RF, f. 05, op. 16, p. 116, d. 22; op. 16, p. 117, d. 23 and 24; op. 17, p. 122, d. 25; op. 17 , p. 128 , d. 24 ; op. 18 , p. 140 , d. 26 and 27.

6. AVP RF, f. 05, op. 16, p. 117, d. 24, 11. 47-51.

7. For example, the political letters of Litvinov to Maiskii during the Rhine land crisis (MarchApril 1936) were not preserved in the delo I have consulted for 1936: AVP RF, f. 05, op. 16, p. 116, d. 22 .

8. I was not allowed to examine Litvinov's letters to the TsK of 1938 and 1939. The explanation was that the dela contained some documents not yet declassified. This is not untypical for the AVP RF: when some documents of a delo are still considered secret, the entire delo is not available. So, even if a few documents are still classified, a relevant percentage of closed files can be contained in a single fond. 
should be an essential instrument for evaluating the character of Litvinov's relations with Stalin and the party leadership. In fact, the letters were addressed to different people, not only to Stalin, which is important for knowing who (and in what way) was involved in decision-making regarding foreign policy (Molotov and Kaganovich in particular). However, not a single answer to Litvinov is available (not only Stalin's). This is obviously a major limitation to the research as it is impossible to infer what the reactions to Litvinov's proposals may have been and what inputs he received from above. Moreover, it is doubtful whether we may be in possession of papers allowing us to at least analyse Litvinov's political orientation fully. For example, there is no tangible evidence of Litvinov's position on Soviet intervention in Spain in the delo containing his letters to the TsK for $1936 .{ }^{9}$ It is therefore very difficult to ascertain whether this was a consequence of self-restraint in his contacts with Stalin, or the result of an archival criterion.

Research experience in the AVP RF on the 1940s presents us with even greater problems. The accessibility of diplomatic correspondence is very limited for the war and post-war years, as only letters from Soviet embassies to Moscow can be examined, but this is not possible for the correspondence from Moscow to Soviet embassies in each single country. In other words, major limitations are imposed on any attempt to analyse the exchange of opinions and information between the Foreign Ministry and Soviet diplomats. The ground for undertaking research is therefore much worse than for the 1930s. Moreover, Litvinov's practice to exchange letters with Stalin and the other CPSU leaders was apparently abandoned by Molotov. This is quite understandable given his much closer personal relationship to Stalin. So, we are deprived of an essential source for understanding policy-making, although in this case we cannot blame the selective opening of the archives.

As a matter of fact, it is much easier to notice gaps than accomplishments in researching the AVP RF: though without knowing with any certainty whether the gaps are a consequence of the structure, of undeclassified materials, or simply of the chance of having received some documents and not others. Our representation of the structure of the fondy of Litvinov's or Molotov's secretariats at Narkomindel (AVP RF, f. 05 and f. 06) is incomplete and approximate (personal files of Litvinov or Molotov do not exist in the AVP RF, while we know that the personal papers of Litvinov and Molotov are preserved in the Archive of the President of the Russian Federation and have only been partially transferred to RTsKhIDNI but have not yet been completely declassified - RTsKhIDNI, f. 359, op. 1; f. 82, op. 1 and 2). The internal documentation of the Ministry of Foreign Affairs (memoranda, working papers, strategic documents, etc.) is largely inaccessible. As for the so-called shifroperepiska (AVP RF, f. 059), it is declassified only for the period up to 1941, but it cannot be consulted for technical and financial reasons, i.e. the need to implement formal declassification and to make working copies. It is not strange that sensitive material about Soviet relations with other countries be made only partially 
accessible. But given the range of documentation involved (embracing all major aspects of foreign policy) this is a major problem, especially for those scholars who undertake research on the Soviet side of the Cold War. ${ }^{10}$

We are often told that the opening of the archives has been more blurred and contradictory than necessary because of a combination of financial problems, inner-bureaucratic competition, and the institutional ineffectiveness of state bodies. The shifrotelegrammy of Narkomindel deserve special attention. In this case, the problem is eminently financial as although documentation dating before 1941 is largely declassified, it might only be consulted in the form of microfilm or microfiches (not yet implemented) because of the danger of damaging the thin paper of the shifrotelegrammy. However, the problem is not only limited to the financial and organisational side. It is believed that shifrotelegrammy, dating to after World War II, cannot be declassified, because they must still be covered by state secret (and by the relevant law). The argument, however, does not seem to be justified as it applies to documents produced forty to fifty years ago, by a State that no longer exists. Nevertheless, the point seems to suggest that a political view, based on the idea of a substantial continuity of Soviet/Russian statehood, is applied to relevant collections of documents and that it influences their declassification. Complaints about rising levels of state secrecy have appeared since 1996, especially related to the Presidential Archive and also to other secret archives. ${ }^{11}$ Similar developments in all the Russian archives (not only in the AVP RF) during the years 1997-1998 seem to support this interpretation, as far as the international papers are concerned.

Be that as it may, the researcher's plans must be filled through documentation collected in other archives and fondy, more or less related to foreign policy processes, though this has become more and more difficult. Or they still have to rely more than expected on the source of the diplomatic collections and (as in the past) on the foreign policy archives of other countries. The publication of relevant foreign policy documents has actually produced valuable results in the last few years. First of all, the 22nd and 23rd volumes of the official diplomatic documents have eventually appeared, after an interruption of about fifteen years. ${ }^{12}$ Important publications of international documents on the war and the post-war years have also appeared. ${ }^{13}$ Such collections are obviously welcomed by historians. There is no

10. See J. Haslam, "Russian archival revelations and our understanding of the Cold War," Diplomatic History, 2 (1997): 219.

11. P. Kennedy Grimsted, Archives of Russia five years later: "Purveyors of sensations" or "shadows cast to the past"?(Amsterdam: International Institute of Social History, 1997) : 181.

12. Dokumenty vneshnei politiki. 1939 god, vol. 22, 1 and 2 (Moscow: Mezhdunarodnye otnosheniia, 1992); Dokumenty vneshnei politiki. 1940-22 iiunia 1941, vol. 23, 1 and 2 (Moscow: Mezhdunarodnye otnosheniia, 1995 and 1998).

13. See SSSR i Germanskii vopros 1941-1949. Dokumenty iz Arkhiva vneshnei politiki Rossiiskoi Federatsii, tom I (Moscow: Mezhdunarodnye otnosheniia, 1996); Vostochnaia Evropa v dokumentakh rossiiskikh arkhivov 1944-1953 gg., tom I (Moscow - Novosibirsk: Sibirskii khronograf, 1997). 
discussion about this, though the criteria applied to the selection of documents often deserve criticism, especially as far as the volumes of diplomatic documents are concerned. ${ }^{14}$ However, our point here is that, in spite of the doubtless interest of such collections, in the present state of archives the risk is that the publication of documents will play the role of a "substitutive factor" of archival research.

One could take the case of the materials of the Narkomindel Commission on the post-war order in the years 1943-1945, headed by Litvinov. ${ }^{15}$ These materials provide us with relevant insights on Soviet views, aims, and concepts of post-war Europe during World War II. ${ }^{16}$ Though there is poor evidence of the relationship of the Commission work with policy-making, we can now investigate internal documents strictly related to security dilemmas (to begin with the German question) and to Soviet ideas on post-war "spheres of influence," which were not available at all earlier. However, while access to the Commission materials has been more and more restricted, most part of the available documents produced on Germany has been published. ${ }^{17}$ Thus, the specialist reader has been provided with a relevant publication, but he has also been deterred from archival research.

As a consequence of this general situation, very often research has to be inevitably oriented on diplomatic approaches, political visions, ideological frameworks, more than on decision-making. A concrete example of this can be seen from the study of the fondy on single countries in the AVP RF. For example, the papers on Italy (AVP RF, f. 098) for the post-war years. The materials available are the politpis'ma of the Soviet ambassador in Rome and the records of the conversations between the Soviet ambassador and Italian political leaders. Even leaving aside a decisive problem, like the unavailability of Moscow's instructions to the ambassador, the character of this documentation is ambiguous. On the one hand, several records of secret conversations at the Soviet embassy, first of all with the communist leaders, are at our disposal. Important political letters addressed by the Soviet ambassador to Moscow can also be examined, shedding light on the content of the conversations, or presenting us with new evidence. These materials contribute substantially to an understanding of the relations between Moscow and the Italian communists, on the co-ordination between the PCI and Soviet foreign

14. An examination of these criteria would entail separate writing. However, it should be noted that some relevant documents are not included in these collections, without any justification. For example, the Soviet record of the meeting between Stalin, Molotov, Ribbentrop and Schulenburg of 27-28 September 1939, and the exchange of messages before the meeting.

15. There is a specific archival classification for these materials: AVP RF, f. 0512. However, several materials of Litvinov's Commission can be found also in Molotov's secretariat (f. 06).

16. Cf. A. Filitov, "Problems of post-war construction in Soviet foreign policy conceptions during World War II," in F. Gori, S. Pons, eds, The Soviet Union and Europe ..., op. cit.: 3-22; V.O. Pechatnov, The Big Three after World War II: New documents on Soviet thinking about post-war relations with the United States and Great Britain (Washington, DC: Wilson Center, 1995), Cold War International History Project, Working paper, 13, July 1995; V. Mastny, Soviet plans for postwar Europe, paper prepared for the Conference "The failure of peace in Europe, 1943-1948" (Florence, June 13-15, 1996).

17. See SSSR i Germanskii vopros ..., op. cit. 
policy, including the years from the dissolution of the Comintern to the founding of the Cominform. On the other hand, the records contain poor evidence on the Soviet position. Moreover, it is likely that the records did not reflect completely the content of the meetings, and even such contents could be interpreted in different ways, since not always a face value reading of what the Italian communists were reporting to the Soviets looks satisfactory. We also know that secret meetings were held between the Soviet ambassador and the Italian communist leaders, which are presumably still preserved in closed files, certainly in the Archive of the President of the Russian Federation. ${ }^{18}$

It seems to me that such archival situation should prevent us from formulating definite conclusions. In other words, we should not be led to believe that undertaking research entitles us to provide definitive answers to all problems. If this is a general warning to be taken into account for anyone approaching Russian archives in their current state, it is of doubtless importance for foreign policy historians. Thus, a paradox can be seen: the main archive for the historical analysis of Soviet foreign policy in Russia does not offer, on very relevant topics, the chance to carry out a complete research. This explains the widespread dissatisfaction of researchers in the field of Soviet foreign policy.

However, it is disputable that research in the history of Soviet foreign policy cannot be undertaken in other former Soviet archives. As a matter of fact, the study of Stalin's foreign policy requires an investigation of the CPSU archives and of the archives of communist international organisations, which should not just be considered as an integration, nor simply finalised to collecting supplementary material. We should rather look at the CPSU papers, at the Comintern and Cominform fondy, and at some personal collections of prominent leaders, as material essential to the analysis of foreign policy, especially concerning historically relevant topics. This obviously depends on their availability, which has recently become more and more difficult. In particular, the osobye papki of the Politbiuro, a source directly related to foreign policy decisions, is only available up to 1934 (RTsKhIDNI, f. 17, op. 162). Therefore what is reported here refers mainly to the pre-1997 situation, assuming that hopefully it will not reveal itself to be just an extraordinary episode and that the opening of archives will not be stopped. Probably, however, we should admit that in the opening of archival documentation on Soviet foreign policy an extremely favourable cycle has developed and exhausted itself approximately in the years 1992-1996.

The Comintern archives at the RTsKhIDNI are decisive for inquiries in the 1930s and in the years of World War II, including the last two years of the war (the documentation preserved in this archive does not end with the dissolution of the Comintern, since its apparatus continued to work and was later reorganised as the Foreign Policy Department of the TsK). Though often poorly related with decisionmaking processes in foreign policy, the documents preserved in this archive can offer important insights, especially through the files of Dimitrov's secretariat 
(RTsKhIDNI, f. 495, op. 73 and 74). A significant example can be found in the documentation on the definition of the Italian and French Communist Party lines in 1943 and 1944, which provided a model for communist strategies in Europe up to 1947.

The work on the critical edition of the Cominform conferences, implemented by the Feltrinelli Foundation, confirms this point. ${ }^{19}$ The documentation of the Cominform fond can be divided into approximately two parts: the working papers which came from the apparatuses - in particular from the Foreign Policy Section of the TsK - and the earlier versions of the speeches of the communist leaders at the conferences (sometimes more than one single version for each speech), which were submitted to editing and abridgement for the minutes. The second part of the documentation has proved to be particularly important for understanding the censorship exercised during the editing of the minutes. However, a critical analysis based on fond 575 would have been very frustrating without the materials of Zhdanov's personal papers (RTsKhIDNI, f. 77, especially op. 3 and 4). In this fond decisive evidence for the first and for the second conference of the Cominform can be found: several different versions of Zhdanov's report prepared on the eve of the first conference (first of all, the so-called chernovik), and also some versions of Zhdanov's report to the second conference; moreover, not less relevant, the secret communications which were sent daily to Stalin by the Soviet representatives at the Cominform conferences of 1947 and 1948, in order to keep him informed about the proceedings and about the off-the-record conversations with the other communist leaders. ${ }^{20}$ In Zhdanov's personal papers several versions of the same message are preserved, including those hand-written by Zhdanov, though we are not sure that the definitive versions are the same which were then sent to Stalin. Such materials present us with the possibility of a better understanding of the decision-making process, which would be impossible on the basis of the Cominform fond. An integration between different fondy is a logical perspective for any research. In this case, the main point is the prominent role played by Zhdanov in the first two Cominform conferences, as the head of the Soviet delegation (the unavailability of Suslov's personal papers impoverishes our knowledge of the third Cominform conference of November 1949).

However, it should be stressed that Zhdanov's personal papers do not contain relevant evidence of Zhdanov's relations with Stalin, though we know that he was

19. See The Cominform. Minutes of the three conferences, op. cit.. The examination of the Cominform fond is made easier by the disposability of detailed finding aids, though the correspondence with the dela contents is not always satisfactory. A large amount of typewritten material forms its bulk: different versions of the same document are preserved, without indicating the date, the author or any other references. Sometimes handwritten notes were added by unknown authors. However, the scholar has at his disposal significant preparatory documentation for the conferences (especially for the first and second conferences).

20. The secret communications sent to Stalin by the Soviet delegates at the first (Zhdanov and Malenkov) and second (Zhdanov, Malenkov and Suslov) Cominform conferences have been published in Soveshchaniia Kominforma 1947, 1948, 1949. Dokumenty i materialy (Moscow: Rosspen, 1998): 315-334, 482-503. 
very close to the Soviet dictator and that, in particular, he had direct links with him during the preparation of the first Cominform conference. Zhdanov sent to Stalin memoranda about the setting of the agenda, and letters enclosed to the draft projects of his report on the international situation, submitted to the vozhd' for his supervision. But we have no evidence of Stalin's inputs. It is difficult to present such lacuna as a consequence of the formation of the fond, since Zhdanov clearly worked on the basis of Stalin's directives, which must have been written directives, at least to some extent. Such lacuna corresponds exactly to the situation of other collections, where in principle Stalin's inputs should supposedly be preserved (for example, the files of Dimitrov's secretary in the Comintern archive).

Even at a lower level one can easily find significant lacunae, both in the collections of the Foreign Policy Department of the TsK and in the Cominform fond. The reasons for this should be discussed. In the papers of the Foreign Policy Department one can find a large amount of information on invidual countries and parties, at times offering important political insights on them (much more in opis' 128 than in opis' 137). But almost nothing is to be found on the point of view of the Soviet leadership. This is clearly a consequence of the function of the Department. Some evidence on the Soviet leaders' thinking is contained only in the few records about the conversations between communist national leaders and the leading officials of the Foreign Policy Department, in particular Zhdanov. ${ }^{21}$ In the Cominform papers the connection between the nature of the documents and the character of the institution is much more uncertain. Starting with the formation of a bureaucratic apparatus in the summer 1948, one could expect to find more materials than is actually available in the Cominform fond. It is worth keeping this in mind as we are led to ask ourselves whether these "blanks" result from the systematic elimination of archival material (there is evidence of such practices for some materials of the fond) or are simply the consequence of the institutional weakness of the Cominform, its dependence on the CPSU organisation, and therefore its difference from the Comintern structure. The preparation of dossiers oriented against national communist leaders like Gomulka and Rajk was actually carried out in the Foreign Policy Department of the CPSU. ${ }^{22}$ Yet, should we think that this type of lacunae are the result of the selective opening of archives (and of the same fond) and that a deeper level of secret documentation (relevant policy-making; criminal or spy activities) is preserved elsewhere?23 All of these hypotheses probably

21. A collection of documents selected from the papers of the Foreign Policy Department of the TsK and from the Cominform papers, on the relations between Moscow and the Italian Communist Party, has recently been published as F. Gori, S. Pons, eds, Dagli archivi di Mosca. L'URSS, il Cominform e il PCI 1943-1951 (Roma: Carocci, 1998) (Fondazione Istituto Gramsci, Annali , 7).

22. See L. Gibianskii, "The last conference of the Cominform," in The Cominform. Minutes of the three Conferences ..., op. cit.: 655-657.

23. We know for certain that several documents were taken away from the current Cominform archive in Bucharest in the 1950s and sent to Moscow, but they are not preserved in the Cominform fond. 
contain elements of truth, though the most likely seems to be the last one, given the highly institutionalized framework of archives in the Soviet system.

How may all these archival materials affect the way scholars view Soviet foreign policy under Stalin? In my opinion, the opening of the archives greatly enriches our understanding of the connection between the Cold War and pre-war Soviet foreign policy, thus challenging the division traced by pre-1991 historical analysis. This, however, should not take us to underestimate previous historical studies. On the contrary, a serious appreciation of previous work and sources is likely to prove the most balanced approach. I do not believe that earlier scholarship will be rendered irrelevant by the study of new archival sources, at least not for a long time. An interaction exists between the research approach and the impact of documentation. Any approach to the Molotov-Ribbentrop pact, for example, would be meaningless without dealing with "old sources" (including memories and the long-standing debate among historians). In other words, although archival documentation has certainly re-oriented any research perspective, this should essentially be a consequence of the interaction between new documents and "old sources."

Nevertheless, stressing the point of the Molotov-Ribbentrop pact, we can now better understand how the pact illustrated the foundations of security strategies destined to re-emerge in the post-war years, after the interlude of the war. A central question is whether real conceptual changes took place in the years 1941-1945, compared to the basic paradigm of the pact of 1939 with Hitler - the priority of territorial security and its expansionist consequences. There exist two schools of thought among historians. One underlines the preponderance of power politics as conceived in 1939 and 1940, while the other appreciates the trends towards collaboration with the Western powers as significant, though not entirely coherent. Both these points of view need to be ascertained through archival documents. As far as we can judge from the materials in our possession, foreign policy alternatives were not reflected in the hypothesis of a prominent contribution of the USSR to consolidating alliances for a new post-war international order, nor in the possibility of breaking with Western partners in order to occupy the geopolitical vacuum created in Europe by the German defeat. Soviet options were much more restricted. There was a choice between a joint or a unilateral definition of the USSR's interest in Europe, both solutions being connected with more or less pessimistic evaluations of the discrepancies between Soviet and Western interests. However, the point is that the 1939 paradigm was not revised. Continuity should not be sought in geopolitical objectives as such. It should instead be found in a foreign policy model, of which those objectives were part, embedded in an ambiguous notion of security. The Soviet strategy was based on the idea that World War II would just have been a stage in an age of catastrophe. The perception of the persistence of war, which was rooted in the pre-war era, prevailed on the idea that international changes brought about by the war offered new foundations for Soviet security. Re-assessment of Soviet strategy for the post-war era was determined neither by the impact of Nazi invasion, nor by the emergence of the conditions for avoiding similar threats in the 
future. It was determined by the end of German power in Europe, and by the fear that a similar threat would eventually re-occur. ${ }^{24}$

In light of this, we should probably abandon any attempt of defining Stalin's foreign policy as either purely realistic or purely ideological. The archives will not be of any use to us, if we fail to appreciate the complexity of this question. There is growing evidence of an interaction between doctrine and geopolitical thinking, and these are not necessarily incompatible. Stalin's unprincipled pragmatism was not detached from his ideological vision, as it was rooted in strategic thinking originating in the Bolshevik doctrine about the inevitability of war. This is not to say that we should take the term "ideology" simply as denoting continuity with the revolutionary tradition. The continuity was in the vision of the outside world. However, there was also a specific dimension of Stalinism, which must be indicated in the foundation of a new concept of security, the concept of a Total Security State emerging in the relationship between the internal regime and the external context.

On the other hand, the image of a "reactive policy" should be dismissed although Stalin's political moves both in the years 1938-1941 and in the years 1944-1947 might lead us to think that. Stalin's decisions instead revealed an underlying strategy. This strategy was neither a simple restoration of the Russian Imperial heritage, nor the continuation of Bolshevik internationalist revolutionary tradition. There is a need for a re-appraisal of the concept of ideology as intended by historians. "It is necessary to establish a wider and more useful definition of ideology, encompassing not only written tradition of authoritative texts and their exegesis but also credenda formed by personal and historical experience." 25 Ideology should be seen as a component of broader political culture, which in the domain of foreign affairs was also shaped according to the knowledge of the external world and the perception of change. An interaction could be determined between different components of political culture, both intentional and unintentional. ${ }^{26}$ This might help avoiding a simplistic picture of political conflict in the Soviet world, achieving a better understanding of the common basis for different and even conflictual tendencies.

Unfortunately, the documentation available in the Russian archives does not shed enough light onto the decision-making processes within the Soviet leadership. Quite clearly, the process was very circumscribed and centralized, even excluding the Politbiuro, which can clearly be seen reading the osobye papki, from crucial decisions. But we don't know much about Stalin's own thoughts yet. Without having proper access to the Presidential Archive, or the transfer of its papers to the open archives, this is not likely to change. Let's take again the founding of the

24. See S. Pons, "The impact of World War II on Soviet security policy," in S. Pons, A. Romano, eds, Russia in the age of wars, 1914-1945, Fondazione Feltrinelli, Annali, 35 (forthcoming).

25. O. A. Westad, "Secrets of the second world: the Russian archives and the reinterpretation of Cold War history,” Diplomatic History, 2 (1997): 264.

26. See T. Skocpol, Social revolutions in the modern world (Cambridge: Cambridge University Press, 1994): 204. 
Cominform. From the archival papers in our possession it is clear that Stalin's role was decisive in the final decisions as Zhdanov submitted to him all the main preparatory documents of the first conference. But this alone is not enough for throwing light on the relations between Stalin and his main deputies, like Zhdanov, Malenkov, and Molotov. However, we can still make some remarks to confirm or dismiss Western historical interpretations before the archives were opened. A provisional picture could be sketched as follows. The new documentation confirms that all the most important decisions were taken by the Soviets and were imposed to the other leaders, although some resistance was opposed to them (for example, by Gomulka at the first conference). Nevertheless, neither during the preparation of the first conference nor its aftermath in the Western communist parties, did the Soviets reveal their commitment to a firm and established political plan carefully prepared in all its substantial aspects. This is something new we have learnt from the archives.

Even the preparatory drafts of Zhdanov's report show significant ambiguity on the part of the Soviet leadership about major political matters. Criticism of some Eastern parties, including the foreign policy of the Yugoslavs in the Balkans, appeared in Zhdanov's first draft report to then disappear in the final version. The German question, which was mentioned as a key point in the first document, sent by Zhdanov to Stalin for approval, was then just mentioned in passing in the actual report. Even the "two camps" thesis did not appear in the first draft of Zhdanov's report. Why were some matters included while others were not? Was it the result of Moscow's hesitancy about the international conduct of the Soviet Union? Was it also a consequence of a division inside the Soviet leadership? Unfortunately, our sources do not allow us to answer the latter question, but they probably allow us to take very seriously the hypothesis of Stalin's hesitancy.

New archival sources do not, in many respects, clarify the ambiguity of the Soviet political mind (or even tend to enforce it). Under this respect, another problem is constituted by what the documents do not tell us. What censorship was exercised on issues concerning international policy in the Cominform documents? This was undoubtedly an aspect of the first conference, for example when the Soviets resisted pressures by the Yugoslavs to put the question of Greece on the agenda. However, the second conference marked the most significant moment: even Zhdanov's report, which was not to be published, only contained few and poor references to international problems, thus avoiding to admit that foreign policy was the central point of conflict between Stalin and Tito, especially in the Balkans. The censorship exercised on international problems clearly shows that the Soviet leadership had no intention of debating foreign policy matters with other communist parties (which were not even given a statement on the conduct of the USSR in Europe on the eve of the Berlin crisis in June 1948) and wanted to establish the concept of limited sovereignty in Eastern European countries. This reflected a more general trend in the communist world, aiming towards the "sterilisation" of political debates. This is a significant part of the work that needs to be done on these documents. In other words, in the former Soviet archives there are 
not only "blanks" resulting from a lack of documentation, but also referring to what the documentation leaves out. This has to be taken into account, as far as the political discourse is concerned.

However, the problem is not only censorship exercised by bureaucratic apparatuses on the transcription of speeches or on records of conversations. The point being that often the protagonists of the political game expressed themselves with major reserves, exercising a sort of self-censorship. This undoubtedly happened at the first Cominform conference in the speeches of communist national leaders, and even more at the second and third conferences. In general, a strong continuity emerges between the official public language and the language used in most parts of the archival documents in our possession, which is often highly formalized. The records of the meetings between the Soviet leaders (Stalin included) and the European communist leaders are only a partial exception. ${ }^{27}$ Only in a few circumstances do we come across sources containing a much freer exchange of opinions, but there is very limited evidence of this, and it generally does not come from the Soviet archives. ${ }^{28}$

All of these remarks present consequences for our understanding of the external dimension of Stalinism in the post-war years. The predominant image is one of Stalin's firm control of the political process, according to a coherent plan for the establishment of the Soviet Bloc and, possibly, for the expansion of Soviet Socialism beyond the frontiers of that Bloc. A substantial part of this image is corroborated by the archival sources. Stalin was actually in control of the Cominform's political process down to the details. In more general terms, it is even beyond our expectations to learn how decisions about the formation of the Soviet Bloc, compared with the formation of the Western Bloc, were restricted to a very limited group of people and were the result of a hierarchical process, not of a negotiated one.

However, this is only one side of the question. The archives teach us different lessons. If we ask ourselves to what extent Stalin's control responded to a political plan and why single decisions were taken, and if we ask such questions in relation with particular moments and documents - then the picture is modified. This is not to say that we can answer any question. This only means that the complexity and subtlety of our views become greater. A variable and even contradictory character of Soviet politics can be seen. As Jonathan Haslam puts it, "foreign policy decisionmaking was inevitably more complicated than the unreal totalitarian image allows." 29 The lines of a general strategy sometimes seem unclear - also because

27. See, in particular, the records of the Stalin-Thorez meetings of November 1944 and November 1947 in Istochnik, 4 (1995) and Istoricheskii arkhiv, 1 (1996).

28. The obvious reference is to some notes of Dimitrov's diary, which has now been published in Bulgaria: G. Dimitrov, Dnevnik, 9 mart 1933 - 6 februari 1949 (Sofia: Universitetsko izdatelstvo "Sv. Kliment Okhridski," 1997). For an "old source" containing such level of evidence, see M. Djilas, Conversations with Stalin (New York, 1962).

29. J. Haslam, art. cit.: 221. 
the set of directives established by the Soviet leaders was often so large and indeterminate that all kinds of political conclusions could be justified in principle.

For example, immediately after the foundation of the Cominform, Western communist leaders made a distinction between criticism addressed them by the Soviets (completely accepted in its consequences both for an international realignment to the USSR and for the launching of a mass campaign against the Marshall Plan) and criticism by the Yugoslavs (rejected in its more radical "insurrectional" implications). Stalin made them understand that the Yugoslav "line" was not on the agenda. However, he did not express his opinion as a definite strategic directive, thus allowing for uncertainty and for different interpretations in the Western communist parties, which contained strong minority factions (as Stalin himself certainly knew) oriented to insurrection. The Soviet leadership avoided maintaining directives bound to tie their hands, in an unpredictable international situation. They did not declare to their allies and comrades the ultimate consequences of the USSR's orientation in the field of foreign policy, which had to be decided according to the circumstances, and was the result of a very circumscribed political process anyway.

It is reasonably doubtful, however, that such a conduct simply corresponded to the obsession for secrecy and to the affirmation of the leading role of the USSR. One also feels scarcely satisfied with the view that the hesitancy in formulating a definite political line was just a deliberate result of Stalin's way of ruling the country and his desire to free himself of any influence. Of course, an answer, if any, will only be provided when we will be allowed to examine his personal papers. Yet, the archival documents on the Cominform provide us with evidence of a deceptive political process, which, I believe, proves the existence of a significant degree of ambiguity in policy-making. In many respects, one could state that the foreign policy line linked to the formation of the Cominform reflected a lack of choice more than a real turn towards a challenging line. This was probably the result of a number of factors and problems in policy-making, and not simply of Stalin's implementation of his despotic rule. Among these was the difficult perception of Western behaviour and the influence of traditional security axioms on the Soviet political mind.

The impressive amount of internal bureaucratic writing on single matters also hardly shows the establishment of a firm political "line." The bureaucratic discourse presented an interlacing of coded phrases with axiomatic statements, which makes the re-construction of policy-making difficult, even with high-level documents. The preparatory papers of the first Cominform conference are a significant example. These drafts contained relevant discrepancies in the analysis of the international situation. On the one hand, a choice was made for presenting bipolarism as the main character of the post-war world, which entailed an underlining of the changes caused by World War II, and some kind of detachment from the thesis of the "capitalist encirclement," which was however not rejected. On the other hand, significant references were made to the traditional concept of "capitalist contradictions" and to the continuity of the old international system. In 
fact, this presents us again with evidence of an ambiguity in Soviet views. While declaring themselves as the main force opposed to American preponderance of power in a bipolar post-war world, the Soviets did not let drop their axioms in the field of international politics. Quite probably, they felt that any other option would have led to an unsafe revision of the theory of the inevitability of war in the Capitalist World, the basic concept for defining Soviet security before World War II, which had to be kept by Stalin until the end of his life. We are not in possession of evidence supporting the hypothesis that such contradictions were also the consequence of a conflict inside the Soviet leadership. However, we have to be careful in drawing the conclusion that the absence of open conflict signifies the absence of complexity in Soviet political behaviour, or even excludes more subtle forms of conflict. That is true also of foreign policy, though the space for interaction or for conflict was much more limited here than in the field of domestic policy.

This does not mean that "uncertainty" or "contradiction" should substitute "planning" as a general model for assessing Stalin's foreign policy. It probably means that we should abandon the idea of analysing policy-making as the product of a strategic design in any moment of Soviet history, since the interaction between ideology, policy-planning and external circumstances has to be taken into account in all its different combinations. The undeniable influence of ideological frameworks and political visions does not always entail the existence of a political strategy (or, such an influence might have been even an obstacle for the exposition of a political strategy). The balance between all of these aspects depends on the questions we ask ourselves on the basis of the new documentation. The archival sources tend to confirm or to modify only in part, rather than change radically, our main interpretations. Even so, this leads to a significant modification of our views and an improvement of our understanding. This is a good reason for carrying out our research in the Russian archives, in spite of all the problems we have to deal with.

\section{Fondazione Istituto Gramsci}

via Portuense 95C

00153 Roma

e-mail :spons@gramsci.it 